\title{
Chromian-spinel Chemistry of a Mesoarchean Metasomatized Ultramafic section from southern India and its Implications to the Crustal Processes
}

\author{
P.M.GEORGE ${ }^{1 *}$ AND MING-GUO ZHAI ${ }^{1,2}$
}

${ }^{1}$ State Key Laboratory of Continental Dynamics,Department of Geology, Northwest University, Xian, CHINA-710069 (*correspondance: gpmaths@nwu.edu.cn)

${ }^{2}$ State Key Laboratory of Lithospheric Evolution, Institute of Geology and Geophysics, Chinese Academy of Sciences, Beijing, CHINA-100029 (mgzhai@mail.iggcas.ac.cn)

Chromian-spinel or $\mathrm{Cr}$-spinel $\left(\left(\mathrm{Mg}, \mathrm{Fe}^{+2}\right)(\mathrm{Cr}, \mathrm{A} 1\right.$, $\left.\mathrm{Fe}^{+3}\right)_{2} \mathrm{O}_{4}$ ) chemistry is widely used a petrogenetic indicator of mafic-ultramafic rocks [1]. This study is on the Cr-spinel chemistry of a metasomatized ultramafic crustal section within ca. 3.35 Ga Sargur group [2] of Dharwar Craton, southern India. The crustal section consists of intercalated komatiite, serpentinite and amphibolite, which are crisscrossed by magnesite veins. Cr-spinels were found to occur only in the komatiite and serpentinite, as accessory mineral within the matrix, having a size ranging from $400 \mu \mathrm{m}-1 \mathrm{~mm}$. Mineral chemistry of the spinel shows no or weak compositional zoning. The $\mathrm{Cr}$-spinels from the serpentinite have high $\mathrm{Cr}_{2} \mathrm{O}_{3}$ content (43.8-49.75 wt \%), low $\mathrm{Al}_{2} \mathrm{O}_{3}(5.9-10.4 \mathrm{wt} \%$ ) with $\mathrm{Cr} \#$ $(\mathrm{Cr} /(\mathrm{Cr}+\mathrm{Al}))$ in the range $0.75-0.85$. On the other hand, the $\mathrm{Cr}$-spinel in the komatiite have very high $\mathrm{FeO}$ content (82-91 wt \%), low in $\mathrm{Cr}$ content (5.7- $10.4 \mathrm{wt} \%$ ) and extremely low $\mathrm{Al}_{2} \mathrm{O}_{3}$ content $(0.05-0.39 \mathrm{wt} \%)$, indicating they are ferritchromite $\left(\mathrm{Fe}^{2+} / \mathrm{Fe}^{3+}=0.99-1.01\right)$. A comparison between the compositions of the Cr-spinels from two ultramafic rocks gives indication to the crustal processes. The composition of the Cr-spinel from the serpentinite suggests their origin due to subduction related processes. While, the $\mathrm{Cr}$-spinels in the komatiite indicate they are altered and have almost converted to magnetite. These alteration processes might have been aided by the emergence of the late magnesite veins. However, it is evident that the Cr-spinel in the serpentinite are likely to have preserved their original composition, although the rock is serpentinized. The results from this study brings more insights to the fluid-rock interaction and the scope of Cr-spinel chemistry to be used as a tracer to understand metasomatic processes [3].

[1]Irvine (1965) Can. J. Earth Sci. 4, 71-103. [2] Jayananda et al. (2008) Precambrian Res. 162,160-179. [3] Gamal El Dien et al. (2019) Nat. Commun. 10, 5103. 